\title{
Exploring the Relationship Between Trees and Human Stress in the Urban Environment
}

\author{
Joseph B. Townsend, Thomas W. Ilvento, and Susan S. Barton
}

\begin{abstract}
The research literature describes a positive relationship between seeing plants and human well-being. More rapid recovery from surgery, reduced incidence of neighborhood crime, increased baby birth weight, and increased trust of neighborhood merchants are among the benefits attributed to exposure to trees and shrubs. This study attempted to find a common explanation for these outcomes. It examined the connection between urban trees and neighborhood stress. Each of the stated outcomes can be attributed, in part, to stress reduction. The literature indicated that stress reduction is one of the consequences of exposure to plants. Stress levels were measured at the block level in Wilmington, Delaware, U.S., by means of a survey mailed to 2,704 residents. Physical conditions were catalogued using an on-site inventory. The survey and inventory demonstrated that the total number of trees on a block has a strong negative relationship with neighborhood stress and a positive relationship with self-reported health. The results suggest that moderation of stress is one of the factors that underlies the beneficial consequences of exposure to green vegetation on inner-city blocks. This research should prove useful to city planners and urban residents alike.

Key Words. Cross-reference Directory; Delaware; Hassles and Uplifts Scale; Human Stress; Perceived Stress Scale; Street Trees; Survey; Tailored Design Method; Tree Canopy; Tree Inventory; Wilmington.
\end{abstract}

Previous studies have documented the contribution of urban trees to the physical environment in cities. Beneficial impacts include pollen reduction (Nowak and McPherson 1993), carbon sequestration (Nowak and McPherson 1993; Cairns and Meganck 1994), reduction of rainwater runoff (Tyrväinen et al. 2005), sound reduction (Pathak et al. 2007), and ambient temperature moderation (Bolund and Hunhammar 1999).

The behavioral impact of tree cover is more difficult to quantify than the physical impact. Nevertheless, data exists to show that views of greenery impact individual well-being and public health (Comas et al. 2010). For example, views of trees have been shown to improve health outcomes (Ulrich 1984), street trees improve the shopping experience (Wolf 2004), landscaping around public housing projects reduces negative social behavior (Kuo and Sullivan 2001a), and the presence of trees on residential streets has a negative correlation with crime rate (Donovan and Prestemon 2010).

Two distinct lines of research run through the literature on the psychological effects of green land- scaping. The first line takes the individual approach. The second examines the effect of tree canopy on the community. Roger Ulrich was one of the first to describe the calming effect natural landscapes have on stressed individuals (Ulrich et al. 1991). He used such physiological measures as heart rate, muscle tension, and skin conductance to measure individual stress. Today, this line of research is expanding to include blood and saliva sampling to determine cortisol levels (Lee et al. 2012; Jiang et al. 2014). In contrast, Kuo and Sullivan (2001b) examined the crime rate at Chicago, Illinois, U.S., housing projects by comparing the aggregated crime rate of an entire building with the presence or absence of exterior landscaping. This research follows the second line by comparing the level of neighborhood stress to the amount of tree cover on a residential city block.

Stress, stressors, and the stress response are terms often confused in common parlance. For this study, stress and stressor are considered synonymous terms. They can be compared to a heavy truck on a metal bridge. The truck, sometimes referred to as the load, is the stressor, it provides stress. The 
sagging of the bridge span is the stress response. For humans, the stress response, especially when chronic, may have negative health consequences.

In this report, the authors sought to understand the relationship between urban trees and neighborhood stress. The focus is on neighborhood trees, both private and public, as opposed to parks and community spaces. It is hypothesized that the quantity of trees, will have a negative correlation with the level of neighborhood stress and that lower neighborhood stress will be confirmed by better self-reported health and sense of safety. To address this issue, a survey of residents in neighborhoods in Wilmington, Delaware, U.S., was completed from autumn 2013 to spring $2014(\mathrm{n}=803$, with a response rate of $41 \%$ ) (Figure 1). The data was aggregated to the block level $(\mathrm{n}=80)$ for the analysis, and additional block level variables were added to the data set. This report summarizes the results of this research.

\section{METHODOLOGY}

\section{The Study Was Conducted in Wilmington, Delaware}

Wilmington is located in the northeastern part of Delaware, along the Christina River and close to the Delaware River and Delaware Bay. It is the largest city in Delaware, with a population of 70,851 (U.S. Census Bureau 2010). The city encompasses 28.23 $\mathrm{km}^{2}$ with a population density of approximately 2,510 people per $\mathrm{km}^{2}$, which is comparable to nearby larger cities of Philadelphia, Pennsylvania, and Baltimore, Maryland, U.S. The city has a large AfricanAmerican population of 58\% (much higher than the $21.4 \%$ for Delaware as a whole) and 32,820 housing units. Wilmington was chosen as the study area because of practical reasons and also because it provided a good opportunity to examine the main hypotheses. The lead author is familiar with the city and its neighborhoods and had a good working relationship with tree organizations and local government. This familiarity was critical in the inventory and tree count data collection for the study.

\section{Wilmington Has a Troubled Racial History}

The city was occupied by the Delaware National Guard for twenty months after the assassination of Dr. Martin Luther King, Jr. in 1968. In comparison to other mid-sized cities, in 2012, "It topped the list in terms of violent crime, outranking 233 other cities for this dubious honor, with 1,703 violent crimes per 100,000 residents" (Nelson 2014). With its polarized racial mix and high crime rate, Wilmington was an ideal location to research the effect of trees on stress.

\section{The Data for This Study Came from Four Main Sources}

The first source for this study was a physical inventory conducted by the lead author, which comprised a visit to each block to conduct a block inventory and tree count. The lead author also used Google Earth $^{\text {Ts }}$ satellite data to calculate tree canopy for each block. A third source of information was a secondary data source for median income and block residences. The fourth source was an individual survey instrument, which was later aggregated to block level measurements. Each source is discussed hereafter.

\section{Criteria for Included Blocks}

For this project, three hundred blocks in Wilmington were selected for their uniform size and their visually observed residential nature using the Google Earth mapping service version 7.1.2.2041 (Google Earth 2013) and Microsoft Bing ${ }^{\circledR}$ (Bing Maps 2014). Tree canopy coverage ranged from $0 \%$ to $100 \%$. Commercial districts, irregular shaped blocks, riverbanks, and freeway entrances were avoided.

Using a cross-reference directory, it was possible to determine the number of inhabited dwellings on each of the three hundred blocks. From the selection of 300 blocks, 150 were chosen that had an adult population of at least 20 residents and no major commercial properties. The selection of 150 blocks was then plotted on a large map of Wilmington to visually check that all city neighborhoods were represented (map not shown). From this sampling frame, eighty blocks were randomly identified. Before the survey was mailed, the criterion was set that in order for a block to be included in the analysis at least five usable surveys had to be returned. With a mean of 25 eligible adults per block, this represents, at a minimum, a $20 \%$ response rate. 


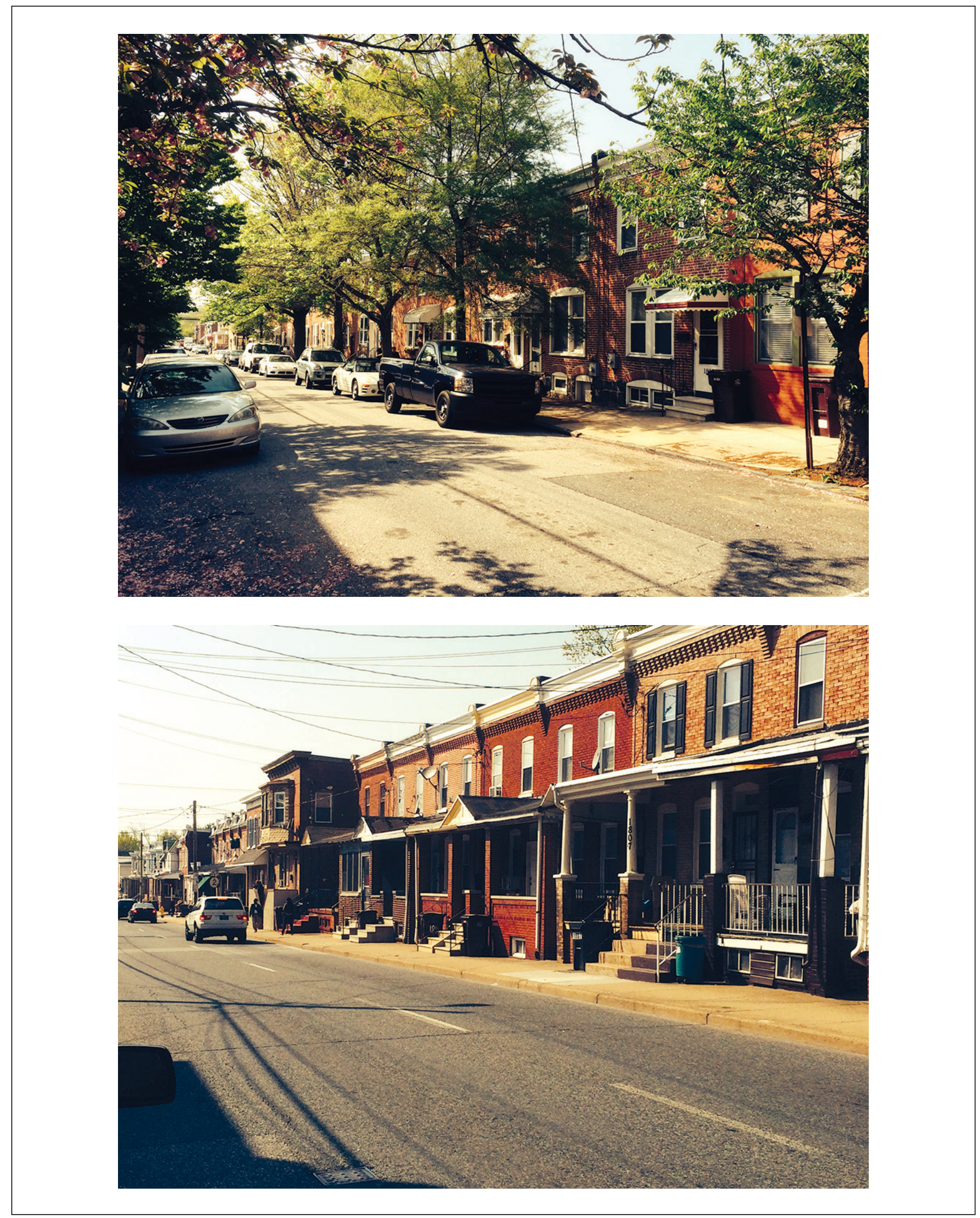

Figure 1.Two streets in the City of Wilmington, one with trees and one without. Data indicates that living on the treed street would be less stressful than on the un-treed street. 


\section{Physical Inventory of Each Block}

A physical inventory card was used to collect onsite data at the block level. The block is defined as the area between the faces of the buildings on each side of the street, extending laterally to the middle of the crossing street. Other block features captured in the inventory include the condition of the sidewalk, estimated height of the tallest building, and the presence or lack of front porches. Notes were made of geographical features, such as hot spots (bars, convenience stores, and check-cashing establishments), adjacent treed streets, nearby shopping districts, nearby parks, and security cameras. The neighborhood was rated for upkeep (a rating with the subcategories of gentrified, tidy, litter, and graffiti), social order (presence of loitering, drinking, drug sales, prostitution) and the presence of abandoned cars, boarded windows, or property damage. The following list was narrowed down to five block characteristics and summated to a single score, Block Features:

1. sidewalk condition

2. presence or lack of front porches

3. level of block upkeep

4. social order

5. physical signs of decline

Three measures of tree cover were gathered:

1. The count of street trees. Street trees are usually planted by the municipality, or the resident, in the sidewalk in spaces cut from the concrete or in strips along the curb prepared when the sidewalk was installed. This count was made by visiting the block.

2. The count of total trees. All trees with canopy extending into the facing block area, including street trees, made up the count of Total Trees. This measure of tree frequency was also calculated by physically visiting the block. This count includes street trees and the adjacent trees not growing in sidewalk planting basins. Some Wilmington blocks have small front yards. Trees growing from these private spaces were included. Essentially, any plant with a canopy and an upright trunk height of more than $1.52 \mathrm{~m}$ was included in the count of Total Trees. Trees on side streets not extending into the facing block area were not included.

3. The percent canopy cover. Canopy cover was calculated from aerial photographs of each block. Aerial photographs downloaded from Google Earth and Microsoft Bing were superimposed on a grid. Once the total number of grid squares comprising the facing block was calculated it was possible to count just the squares over the tree canopy. The percent canopy cover is the number of squares over the trees divided by the total squares on the facing block.

The three tree measures, Street Trees, Total Trees count, and percent Canopy are related measures, but each captures something a little different from the other. To understand the impact of trees on stress, it is important to have the most accurate measure possible. To refine the measures one step further, Street Trees was subtracted from Total Trees to produce an Other Tree measure. This is the count of trees growing in the alleys, on the front lawns and extending into the facing block from adjacent streets. Table 1 shows how these four measures are related. Since Canopy is strongly related to Total Trees, and Street Trees and Other Trees are two components of the total, Street Trees and Other Trees were used in the analysis as measures of trees. The breakdown into these two types allows for separate effects of trees based on what the municipality can influence and what homeowners can influence.

Table 1. Correlation between tree cover measures.

\begin{tabular}{lllll}
\hline & Total trees & Street trees & Other trees & Canopy \\
\hline Total trees & 1.0000 & & & \\
Street trees & 0.8014 & 1.0000 & & \\
Other trees & 0.6051 & 0.0091 & 1.0000 & \\
Canopy & 0.7738 & 0.6653 & 0.4077 & 1.0000 \\
\hline
\end{tabular}

\section{Secondary Data Source}

A secondary source of data was used for median income of the block. The study authors had concern that a possible correlation between median income and neighborhood stress would provide an alternate explanation for the effect trees have on stress at the block level. By factoring median income into multiple regression analysis, a control for its impact was added. The authors would have preferred to use median income drawn from U.S. Government census data, however, the smallest geographic unit available is the census tract. The census tract is too large a unit of measure for evaluating the impact of tree cover on neighborhood residents. As an alternative, a Wilmington cross-reference directory was 
used (Consumer and Business Guide for Wilmington, Delaware and Vicinity 2012-2013 Edition 2012). Cross-reference directories compile information on the residents and businesses of major American cities by tracking census data, telephone directories, and other public records. These directories are used by businesses to locate customers and create customized mailing lists. A typical directory will list city streets in alpha-numeric order followed by residential names and addresses. Businesses on the street are included. Beside each address will be the names of residents over eighteen years of age and any available telephone numbers. The listing for each street also includes the number of residents, the census tract, and the median income. At the back of the book, all telephone numbers for that particular urban center are listed in numeric order followed by name and street addresses. The cross-reference directory provided median income data at the street level. A representative from one of the directory companies explained that income numbers were modeled by street. Factors, such as the census statistics, real-estate value, warranty response lists, billing statements from bank cards, magazine subscriptions, and mortgage information were among the more than 75 sources used. The accuracy of the model is essential to the usefulness of the list as a marketing tool. This explanation was sufficient to proceed with median income data at the street level provided by a commercial enterprise.

\section{Survey Data Collection}

A third source of data for this study was collected from surveys of individual residences in Wilmington. The survey document was titled "Community Life Survey" (Townsend 2014). It gathered limited biographical data but focused more directly on what it was like to live on the respondent's specific block. Most important were two multiple-question sociological measures of neighborhood stress. A mailing list of 2,704 names and addresses was used to send the direct mail questionnaire to block residents. The list of resident names and addresses came from two different cross-reference directories (Consumer and Business Guide for Wilmington, Delaware and Vicinity 2012-2013 Edition 2012; Targeted Sales Leads | Consumer \& Business Sales Leads | Salesgenie 2014). The listings from each directory of names and addresses in the 80 selected blocks were combined. Duplicate names were removed. On blocks where inhabitants rapidly move in and move out, it is difficult to capture an accurate list of who lives on the block at any one time. One list might be as much as $20 \%$ different from the other. It was unclear which was more accurate. The combination of the two directories produced a list more likely to catch all of the residents.

The survey was reviewed and approved by the University of Delaware Institutional Review Board. The survey was conducted from November 2013 through March 2014. Dillman's "tailored design method" was used to guide the survey process (Dillman 2009). This involved multiple contacts to encourage response and strategies to build rewards, reduce costs, and build trust. For example, all contacts were made using the University of Delaware letterhead and a financial incentive (USD \$2.00) was used in the initial survey mailing. The contacts were made in the following order: first, a mailed letter announcing the survey; second was the first mailing of the survey with the financial incentive; this was followed by a postcard reminder; finally all non-responding addresses were visited and door hangers were left with a new survey. Of the initial 2,704 names and addresses, 722 were returned because of bad addresses. The revised mailing list contained 1,982 addresses. Eight hundred thirtysix residents responded to the survey for a response rate of $42.2 \%$. The usable number of surveys was 810 . These were used to calculate block averages for the dependent variables on the 80 randomly selected blocks and to validate the stress scales.

\section{Measures of Stress}

Two measures of stress, reflecting different theoretical aspects, were used in this study, the Hassles and Uplifts Scale (HAUS) (DeLongis et al. 1988; Steptoe and Feldman 2001; Agyemang et al. 2007) and the Perceived Stress Scale (PSS) (Cohen et al. 1983).

The HAUS is the summation of survey responses from fourteen questions regarding life on the block. This strategy is similar to contemporary cumulative risk assessment used by the U.S. Environmental Protection Agency (EPA). It is a concept that originated in the 1986 EPA guidelines for determining health effects of exposure to chemical mixtures (Sexton and Linder 2011). After a series of steps to determine exposure tox- 
icity, the EPA suggested that the default option is to assume that constituent actions are additive (U.S. EPA 1986). This approach was borrowed by sociologists and used in the modeling of the causes of the health gradients in urban neighborhoods (Evans and Kim 2010). The basic idea is that individuals may be exposed to more than one risk at a time. Some risks are chemical, some are social, and some are related to the physical environment. Multiple exposures may have a synergistic effect on the individual or they may cause less harm than expected (Sexton and Linder 2011).

The HAUS, in the tradition of Richard Lazarus (Lazarus 1997), measures stress by calling to mind specific irritants and benefits in the immediate surroundings. In this study, respondents were not asked if they were stressed or to report on litter, street noise, or police patrol, but instead, they were asked to reflect on the impact each item had on the quality of life on their block. Three possible responses were provided-no impact, slight impact, and large impact. The internal consistency (Cronbach's alpha) based on individual data for the HAUS scale was 0.79 (a value of 0.70 or higher is considered valid for a scale). The 14 items included:

1. Sense of community

2. Street drug sales

3. Friendly neighbors

4. Young people loitering

5. Street rubbish

6. Street noise

7. Good park sites nearby

8. Traffic

9. Graffiti

10. Police patrol

11. Unemployment

12. Street lighting

13. Absentee property ownership

14. Commercial establishments, such as bars, night clubs, or convenience stores

Cohen et al. first reported on their PSS in 1983. In contrast to the HAUS, the PSS is based on an individual's internal sense of efficacy. Like the HAUS, the PSS predicts psychological symptoms, physical symptoms, and health behaviors based on a multi-item scale.
Originally it was a 14-item scale. This project employed a well-validated ten-item version. Respondents were asked to rate the 10 items by checking off the descriptors: Never, Almost Never, Sometimes, Fairly Often, and Very Often (some items were reversed in the scale because they reflected positive responses). The larger the summed score, the more stress for the PSS scale. The internal consistency (Cronbach's alpha) based on individual data for the PSS scale was 0.85 (a value of 0.70 or higher is considered valid for a scale). The questions for this scale included:

1. In the last month, how often have you been upset because of something that happened unexpectedly?

2. And in the last month, how often have you felt that you were unable to control the important things in your life?

3. In the last month, how often have you felt nervous and stressed?

4. In the last month, how often have you felt confident about your ability to handle your personal problems? (item was reversed)

5. In the last month, how often have you felt that things were going your way? (item was reversed)

6. In the last month, how often have you found that you could not cope with all the things that you had to do?

7. And the last month, how often have you been able to control irritations in your life?

8. In the last month, how often have you felt that you were on top of things? (item reversed)

9. In the last month, how often have you been angered because of things that were outside of your control?

10. And in the last month, how often have you felt difficulties were piling up so high that you could not overcome them?

Since trees were counted by block, it was necessary to aggregate both the HAUS and the PSS from the individual to the block level (Agyemang et al. 2007). A block is a neighborhood 
with clearly defined boundaries-the crossing streets. Interactions among residents are often constrained by these boundaries. The neighborhood has been shown to have a significant impact on health and well-being "over and above individual deprivation levels and psychosocial characteristics in both the United States and the United Kingdom" (Steptoe and Feldman 2001).

According to the literature, there is a correlation between stress and safety, and stress and health (Nasar and Jones 1997; Sapolsky 2004; McEwen and Gianaros 2010). In order to further verify the measures of stress here (HAUS and PSS), researchers looked at two single questions reflecting perceived safety and health. The survey questions are listed below.

How safe do you feel walking alone at night on the block where you live? This question had four responses from Very Unsafe (coded as 1) to Very Safe (coded as 4 ). The average block level of Safety was 2.37 with a standard deviation of 0.46 .

How is your health in general? This question had five responses from Poor (coded as 1) to Excellent (coded as 5). The average block level of Health was 3.47 with a standard deviation of 0.49 .

The study authors expected that the measures of Safety and Health would be negatively correlated with the measures of stress, both at the individual and block levels (Table 2 ). The data confirmed that the correlations are negative. The correlations with HAUS were substantially higher than those with PSS.

Based on these associations, the HAUS and the PSS measures are further validated for use in the regression analysis.

Table 2. Correlations of safety and health with the stress measures at the individual and block levels.

\begin{tabular}{llllll}
\hline & \multicolumn{2}{l}{ Individual } & & \multicolumn{2}{l}{ Block } \\
\cline { 2 - 3 } & Safety & Health & & Safety & Health \\
\hline HAUS & -0.44 & -0.21 & & -0.71 & -0.55 \\
PSS & -0.27 & -0.33 & & -0.32 & -0.38 \\
\hline
\end{tabular}

\section{RESULTS}

The unit of measurement for this project is the city block. The physical components of the block environment were inventoried by an onsite inspection. The individual opinions and observations of block residents were recorded using a survey. To make valid comparisons between a block's physical features and individual opinions and observations, it was necessary to aggregate individual data to the block level. Table 3 shows some of the characteristics of the study population before aggregation.

The study population was $62 \%$ female and $38 \%$ male. Gender percentages taken from the 2010 Wilmington census were $53 \%$ female and $47 \%$ male. The considerable difference between these statistical reports is not unusual for such surveys, and the authors did not think it demonstrated bias. The survey literature suggests that women typically have a higher response rate than men (Smith 2008). The respondents also reflected a bias toward higher educated (51\% were college educated). Reported ethnic background showed that almost half of the survey participants were Afro-American (48\%), which is consistent with the racial makeup of Wilmington. Six percent of the respondents declined to designate their ethnicity. The mean ages of women and men were very similar (49 and 50, respectively). None of the figures were highly skewed.

Table 3. Characteristics of the study population from the survey.

\begin{tabular}{ll}
\hline Participant characteristic & $\#$ \\
\hline Number of participants & 810 \\
Number of blocks & 80 \\
Respondents per block (min-max) & $5-27$ \\
& \\
Gender & \\
$\quad$ Male & $38.0 \%$ \\
$\quad$ Female & $62.0 \%$ \\
Ethnicity & \\
$\quad$ Black & $48.0 \%$ \\
$\quad$ White & $44.0 \%$ \\
$\quad$ Asian & $0.5 \%$ \\
$\quad$ Other & $0.6 \%$ \\
$\quad$ Declined to answer & $6.0 \%$ \\
Highest education level completed & \\
$\quad$ Primary school & \\
$\quad$ Secondary school & \\
$\quad$ High school & $0.6 \%$ \\
$\quad$ University & $2.0 \%$ \\
$\quad$ & $46.0 \%$ \\
Age & $51.0 \%$ \\
$\quad$ Mean female & \\
$\quad$ Mean male & \\
\hline
\end{tabular}




\section{Variables in the Analysis}

The following variables are used in the analysis. Many are based on block averages based on the survey. Others are block averages based on the physical inventory by the main author or secondary data sources. Table 4 lists each variable name, the source of the data, and a brief description. This is followed by Table 5, which provides descriptive statistics for each variable. All variables are based on a sample size of 80 blocks. HAUS, Street Trees, Other Trees, Median Income, Block Features, and Average Age show considerably more variation than the remaining variables.

Table 6 shows the correlations of all usable variables gathered from the survey and physical inventory plus median income, which was drawn from the cross-reference directories. Not all of the data gathered by the inventory and survey is used in the analysis; in some cases, the responses were so irregular as to make comparison with other terms meaningless. One such variable is baby birth weight. For this variable, the block population was far too small to generate useful data. Birth weight comparisons with treed streets work at the epidemiological level (Donovan et al. 2011) but not at the block level. Another unused variable is ethnicity. Because the unit of measurement was the block, the only way to report ethnicity would be as a block average. This seemed an unnecessary exercise considering that Eitle and Turner (2003) demonstrate it is not ethnicity but exposure to environmental factors that is significant in predicting behavior in the neighborhood.

Table 7 and Table 8 use two different measures of stress-the PSS and the HAUS-in multiple regression models. In this analysis, the PSS and the HAUS are dependent variables, and Street Trees, Other Trees, Median Income, and Block

Table 4. The variable names, source, and description of the variables used in the analysis.

\begin{tabular}{|c|c|c|}
\hline Variable name & Source & Description \\
\hline HAUS & Survey & $\begin{array}{l}\text { The HAUS is an additive scale of } 14 \text { items measuring community stress using questions that } \\
\text { are personal evaluations of external stimuli. The measure used is a block average. }\end{array}$ \\
\hline StreetT & Inventory & $\begin{array}{l}\text { A count of the number of municipal trees on the facing sides of the street. No trees on side } \\
\text { streets were included. The number given is the block total. }\end{array}$ \\
\hline OtherT & Inventory & $\begin{array}{l}\text { A count of the all trees between the facing block buildings, except street trees. It was calculated } \\
\text { as the difference between the total trees and the number of street trees. }\end{array}$ \\
\hline MedInc & Secondary & Median income of the block, taken from a secondary data source, expressed per USD \$1,000. \\
\hline BlkFeat & Inventory & $\begin{array}{l}\text { An additive scale of five block features reviewed by the main author that reflect negative } \\
\text { aspects of the block. }\end{array}$ \\
\hline Age & Survey & The average age of respondents on the block, based on the information given in the survey. \\
\hline Educ & Survey & $\begin{array}{l}\text { The average block proportion of college-educated respondents, based on the information } \\
\text { given in the survey. }\end{array}$ \\
\hline Employ & Survey & $\begin{array}{l}\text { The average block proportion of employed respondents, based on the information given in } \\
\text { the survey. }\end{array}$ \\
\hline Owner & Survey & $\begin{array}{l}\text { The average block proportion of owner-occupied houses, based on the information given in } \\
\text { the survey. }\end{array}$ \\
\hline Crime & Survey & $\begin{array}{l}\text { The average block proportion of respondents who indicated crime on their block in the last } \\
\text { month, based on the information given in the survey. }\end{array}$ \\
\hline Police & Survey & $\begin{array}{l}\text { The average block proportion of respondents who indicated a police visit on their block in the } \\
\text { last month, based on the information given in the survey. }\end{array}$ \\
\hline Safety & Survey & $\begin{array}{l}\text { The block mean response to a four-item Likert scale, with } 4 \text { indicating Very Safe, based on the } \\
\text { information given in the survey. }\end{array}$ \\
\hline Health & Survey & $\begin{array}{l}\text { The block mean response to a five-item Likert scale, with } 5 \text { indicating Excellent, based on the } \\
\text { information given in the survey. }\end{array}$ \\
\hline PSS & Survey & $\begin{array}{l}\text { The PSS is an additive scale of } 10 \text { items measuring community stress using questions that } \\
\text { inquire about personal efficacy. The measure used is a block average. }\end{array}$ \\
\hline
\end{tabular}


Features are independent variables. The primary interest is in the Street Trees and Other Trees variables, but these are tested while controlling for the other independent variables in the model.

Table 7 and Table 8 model the PSS and the HAUS on eleven independent variables. The strategy for this analysis was to sequentially add new variables to the model to allow for change in the fit (Adjusted $\mathrm{R}^{2}$ ). At the same time, it was possible to

Table 5. Descriptive statistics of variables in the regression models.

\begin{tabular}{lrcrr}
\hline Variable & Mean & Std. Dev & Min & Max \\
\hline HAUS & 26.64 & 2.78 & 20.17 & 31.88 \\
StreetT & 6.60 & 6.09 & 0.00 & 25.00 \\
OtherT & 3.75 & 4.56 & 0.00 & 23.00 \\
MedInc & 34.85 & 8.74 & 15.00 & 58.00 \\
BlkFeat & 2.41 & 1.80 & 0.00 & 7.00 \\
Age & 50.41 & 7.10 & 27.00 & 65.00 \\
Educ & 0.45 & 0.28 & 0.00 & 1.00 \\
Employ & 0.61 & 0.21 & 0.00 & 1.00 \\
Own & 0.58 & 0.29 & 0.00 & 1.00 \\
Crime & 0.42 & 0.18 & 0.00 & 0.83 \\
Police & 0.65 & 0.23 & 0.00 & 1.00 \\
Safety & 2.37 & 0.46 & 1.40 & 3.50 \\
Health & 3.47 & 0.49 & 2.50 & 4.50 \\
PSS & 13.98 & 2.95 & 7.30 & 20.60 \\
\hline
\end{tabular}

examine how the coefficients changed in size and the significance changed when new variables were entered into the models. For each table, Model 1 includes the two measures of tree cover (Street Trees and Other Trees). Model 2 includes the tree cover measures plus Median Income and Block Features in an attempt to account for the relationship with trees. These two variables are the main rival hypotheses and provide a better test of whether trees influence the PSS or the HAUS. Issues of collinearity were checked for each model using a VIF measure (Variance Inflation Factor). Model 3 adds an additional set of covariates to test the essential relationship of the PSS and the HAUS to tree cover. Model 4 is a reduced model that includes only the significant variables from Models 1-3. The standardized coefficients are included with Model 4 to compare the relative effects of each variable.

Table 7 shows the results of four models regressing the PSS on ten variables. Model 1 regressed the PSS on Street Trees and Other Trees (these two measures combined equal the total of all trees on the block). In this model, Street Trees were not

Table. 6. Correlations of variables in the regression models.

\begin{tabular}{|c|c|c|c|c|c|c|c|c|c|c|c|c|}
\hline & HAUS & StreetT & OtherT & MedInc & BlkFeat & Age & Educ & Employ & Own & Crime & Police & PSS \\
\hline HAUS & 1.00 & & & & & & & & & & & \\
\hline StreetT & -0.29 & 1.00 & & & & & & & & & & \\
\hline OtherT & -0.57 & 0.01 & 1.00 & & & & & & & & & \\
\hline MedInc & -0.62 & 0.03 & 0.46 & 1.00 & & & & & & & & \\
\hline BlkFeat & 0.57 & -0.18 & -0.47 & -0.38 & 1.00 & & & & & & & \\
\hline Age & 0.13 & -0.23 & 0.09 & 0.14 & -0.06 & 1.00 & & & & & & \\
\hline Educ & -0.55 & 0.19 & 0.56 & 0.37 & -0.59 & -0.08 & 1.00 & & & & & \\
\hline Employ & -0.38 & 0.18 & 0.30 & 0.20 & -0.32 & -0.40 & 0.57 & 1.00 & & & & \\
\hline Own & -0.24 & 0.04 & 0.35 & 0.30 & -0.44 & 0.30 & 0.42 & 0.07 & 1.00 & & & \\
\hline Crime & 0.11 & 0.08 & -0.09 & 0.03 & 0.02 & -0.02 & 0.09 & 0.14 & 0.00 & 1.00 & & \\
\hline Police & 0.27 & 0.09 & -0.19 & -0.08 & 0.21 & 0.10 & -0.21 & -0.14 & -0.12 & 0.19 & 1.00 & \\
\hline PSS & 0.36 & 0.11 & -0.23 & -0.34 & 0.20 & -0.18 & -0.25 & -0.09 & -0.23 & -0.02 & 0.08 & 1.00 \\
\hline
\end{tabular}

Table 7. Models of the PSS by Street Trees and other independent variables.

\begin{tabular}{|c|c|c|c|c|c|}
\hline Variables & Model 1 & Model 2 & Model 3 & Model 4 & Std B \\
\hline Intercept & $14.18^{* * *}$ & $16.73^{\star * *}$ & $17.92^{\star *}$ & $18.04^{* * *}$ & \\
\hline Street Trees & 0.05 & 0.06 & 0.05 & & \\
\hline Other trees & -0.15 & -0.03 & 0.00 & & \\
\hline Median income & & $-0.10^{*}$ & $-0.09^{*}$ & $-0.12^{\star *}$ & -0.34 \\
\hline Block features & & 0.15 & $-5 e-3$ & & \\
\hline Age & & & -0.04 & & \\
\hline Education & & & -1.53 & & \\
\hline Employment & & & -0.42 & & \\
\hline Ownership & & & -0.96 & & \\
\hline Socialize & & & 2.26 & & \\
\hline Experienced crime & & & 0.12 & & \\
\hline Report police visits & & & 0.08 & & \\
\hline Adjusted $\mathrm{R}^{2}$ & 0.04 & 0.10 & 0.05 & 0.11 & \\
\hline
\end{tabular}

Note: Single asterisk $\left(^{*}\right)=P<0.05$; double asterisk $\left(^{* *}\right)=P<0.01$; triple asterisk $\left({ }^{* *}\right)=P<0.001$ (2 tail). 
significant $(P=0.33)$. Other Trees are significant $(P=0.04)$. For the whole model, the $P$-value is 0.08 . There is almost no relationship between tree cover and the PSS. The Adjusted $\mathrm{R}^{2}$ for the model is 0.04 , meaning the two tree variables account for as little as $4 \%$ of the variance in the PSS.

Model 2 added two variables to the mix, Median Income and Block Features. Median Income is negatively related and is significant. However, while the coefficient for block features is positive, it is not statistically significant. The Adjusted $\mathrm{R}^{2}$ for the model improves to 0.10 .

Model 3 adds seven more variables to the analysis. Median Income remains negatively significant but none of the additional variables are significant. The explanatory value of the model drops to Adjusted $\mathrm{R}^{2}=0.05$. Removing Median Income from the model does not change the significance of any of the other variables.

Model 4 only included the one factor that remained significant through the previous models, Median Income. With only Median Income as a variable, the $P$-value was significant $(P$ $=0.002)$ and the Adjusted $\mathrm{R}^{2}$ value was 0.11. There is no evidence that trees have an impact on bock level stress that is measured by the PSS.

Overall, the models in Table 7 show that the PSS is not responsive to either the count of Street Trees or the count of Other Trees on the block. The $P$-values for these variables are higher than 0.05 . The basic reasoning behind the PSS is that lack of self-efficacy produces stress (Cohen et al. 1995). Self-efficacy is the individual's sense that in the face of challenges he or she can get things done. The fact that this is an internal psychological construct may explain why it does not vary with the amount of tree cover on the block. The PSS did vary with one factor, Median Income $(P<0.01)$. Median income is related to social efficacy (Adler and Stewart 2004). Those with greater means are able to do more. They can buy bigger cars, have nicer houses, and afford a better education. Higher median income provides social status and feels good (Sapolsky 2005). The conclusion is that the PSS is reasonably good at what it was designed to do, predict a level of psychological stress that has an impact on health outcomes. It is not useful in measuring the contributions trees make to life on the block.

Table 8 matched the HAUS score with Street Trees, and eleven other variables in four linear regression models. Model 1 regressed the HAUS by Street Trees and Other Trees. Together these two measures comprise all the trees on the block. In contrast to the PSS model, trees do have a moderate impact on block HAUS stress. In this model, Street Trees and Other Trees showed a moderate negative relationship that was statistically significant. The Adjusted $\mathrm{R}^{2}$ for the model was 0.39.

Model 2 adds two variables to the mix, Median Income and Block Features. Street Trees and Other Trees were negative and significant. Median Income was also negatively related and significant. The coefficient for Block Features was positive and significant. The Adjusted $\mathrm{R}^{2}$ for the model improved to 0.58 . Model 3 adds seven more variables to the analysis. Street Trees, Other Trees, and Median Income remain

Table 8. Models of the HAUS by Street Trees and other independent variables.

\begin{tabular}{|c|c|c|c|c|c|}
\hline Variables & Model 1 & Model 2 & Model 3 & Model 4 & Std B \\
\hline Intercept & $28.80^{* * *}$ & $31.38^{* * *}$ & $29.54^{* * *}$ & $31.38^{\star * *}$ & \\
\hline Street trees & $-0.13^{\star *}$ & $-0.11^{\star *}$ & $-0.09^{\star *}$ & $-0.11^{\star *}$ & -0.23 \\
\hline Other trees & $-0.34^{* * *}$ & $-0.16^{\star *}$ & $-0.12^{\star}$ & $-0.16^{\star *}$ & -0.27 \\
\hline Median income & & $-0.13^{\star * *}$ & $-0.14^{\star * *}$ & $-0.13^{\star * *}$ & -0.39 \\
\hline Block features & & $0.39^{\star *}$ & $0.35^{\star}$ & $0.39^{\star *}$ & 0.25 \\
\hline Age & & & 0.04 & & \\
\hline Education & & & -1.15 & & \\
\hline Employment & & & -0.06 & & \\
\hline Ownership & & & 1.19 & & \\
\hline Socialize & & & -1.97 & & \\
\hline Experienced crime & & & 1.48 & & \\
\hline Report police visits & & & 1.67 & & \\
\hline Adjusted $\mathrm{R}^{2}$ & 0.39 & 0.58 & 0.63 & 0.58 & \\
\hline
\end{tabular}

Note: Single asterisk $\left({ }^{*}\right)=P<0.05$; double asterisk $\left.{ }^{* *}\right)=P<0.01$; triple asterisk $\left({ }^{* *}\right)=P<0.001$ (2 tail). 
negatively significant. Block Features remained positively significant. None of the additional variables were significant. The explanatory value of the model increased slightly (Adjusted $\mathrm{R}^{2}=0.63$ ).

Model 4 used only the variables that maintained significance in the previous three models. The HAUS is regressed on Street Trees, Other Trees, Median Income, and Block Features. Like Model 2, Street Trees $(P=0.002)$ and Other Trees $(P=0.003)$ have negative significance. Block Features was positively significant $(P=0.004)$, while Median Income, still negative, was highly significant $(P \leq 0.001)$. The model explained $58 \%$ of the variance in the HAUS score. Based on the VIF, none of the final variables has issues of collinearity.

In contrast to the PSS, the models for the HAUS in Table 8 show that trees (both Street Trees and Other Trees) contribute to a reduction of stress on the block. The reasoning behind the HAUS is that environmental factors both psychological and physical may contribute to stress when they are seen as challenging. Stress comes first from a subconscious appraisal and then from a conscious appraisal that some things or events may tax individuals beyond their abilities. In contrast to the PSS, the HAUS is very responsive to both Street Trees $(P<0.01)$ and Other Trees $(P<0.01)$ on the block. The Adjusted $\mathrm{R}^{2}$ shown in Table 8, Model 1 is 0.39 . This means that Street Trees and Other Trees account for 39\% of the change in the HAUS measure of stress. Like the $P S S$, the HAUS also shows a strong connection to Median Income $(P<0.001)$. Unlike the PSS, the HAUS is moderately impacted by Block Features in addition to trees $(P<0.01)$. While five of the seven other independent variables show significant impact on the HAUS when fitted individually (Education, Socialize, Employed, Home Ownership, and Reporting Police Visits) none of them have significance in the full model.

\section{DISCUSSION}

By means of a physical inventory and a survey of 80 randomly selected blocks in Wilmington, Delaware, it was possible to examine the relationship between the amount of tree cover on a block and the level of neighborhood stress. Both the inventory and the survey incorporated redundant instruments for measuring variables. There were three differ- ent measures of tree cover, two different measures of stress, and two measures to validate the stress scores. Not every measure performed as intended, but the conclusion is undeniable that tree cover does have a significant impact on neighborhood stress.

Regarding the best method for measuring urban tree cover, the physical inventory of eighty blocks in Wilmington produced three tree cover measures: Total Trees, Street Trees, and Other Trees. Analysis of the data showed that Street Trees and Other Trees were moderately significant in their impact on neighborhood stress (HAUS) in a negative direction. According to Table 3, Street Trees and Other Trees have very little correlation (0.009). They explain different things about the tree cover on the block. In future research, to determine the measure of tree cover on a block, the dual count of street trees and other trees is a robust measure to use. Together they capture the large picture and separately they provide detailed information.

The distinction between Street Trees and Other Trees in calculating stress reduction is an important contribution of this research. In the HAUS models, Street Trees and Other Trees together account for as much as $39 \%$ of the variance in the reported level of block stress. Regressed individually on the HAUS, Street Trees has an Adjusted $\mathrm{R}^{2}$ of 0.07 and Other Trees has an Adjusted $\mathrm{R}^{2}$ of 0.31 (models not shown). For city administrators and urban planners, the recognition that both types of tree cover contribute to the overall positive effect of tree canopy in a neighborhood has practical application. Street trees provide a significant contribution but private trees (Other Trees) substantially augment that relationship. Where planting street trees is not a viable option, encouraging private tree planting and tree maintenance is an alternative solution. In a 2005 study on enhancing Wilmington's Brandywine Valley Scenic Byway, three examples of "borrowed trees" are mentioned. Wilmington and Brandywine Cemetery, Trinity Church, and the Delaware Children's Theatre, all on Delaware Avenue, provide:

existing openspace housing trees that are critical to the tree canopy of Delaware... Even though these trees are growing on private land, the city should regard them as valuable resources and should play an active role in their stewardship. This 
may mean providing assistance for their maintenance and replacement. (Barton et al. 2005)

Confirmation that physical street tree inventories are still relevant is the second contribution of this research. Measuring trees by physical inventory is a time-tested method for gathering data about a city's tree population. More recent developments in satellite imagery have taken the panache out of actually walking the streets and recording tree data. Unfortunately, when using satellite photography, it is often difficult to distinguish between municipal trees and private trees. This project demonstrates that actual neighborhood footwork provides insight to the tree canopy that aerial photography cannot provide. It also shows that the tree count and the percent tree cover are highly correlated (0.77). Where aerial photography is prohibitively expensive, the tried and true physical inventory is a viable substitute.

The third major contribution of this research is the contrasted applicability of the PSS and the HAUS in environmental stress evaluation. The HAUS was highly responsive to the physical environment, such as tree cover and block conditions. The PSS was not responsive to these variables. The only variable that impacted the PSS was Median Income. It also impacted the HAUS. The PSS and the HAUS seem to represent two different aspects of stress. The PSS is an internal psychological measure, while the HAUS is an environmental measure. Since both have a strong relationship with sense of safety and health, the conclusion must be drawn that stress is not a singular phenomenon but a complex of perceptions and emotions that contribute together to the stress response.

Sheldon Cohen built his perceived stress scale as a streamlined survey instrument to establish an objective level of community stress. Contemporary sociologists were focusing on life events as the source of stress (Cohen et al. 1993). In contrast, Richard Lazarus focused on personal hassles (DeLongis et al. 1988). The difference in correlations between health outcomes and the PSS $(-0.38)$ and health outcomes and the HAUS $(-0.55)$ is substantial. If health outcomes are the measure of how relevant a stress measure is, then a scale like the HAUS, which calls to mind specific irritants rather than general malaise, comes out a strong winner. It may be a little more cumbersome to use, but the results are much stronger.

The one emotion that both stress models have in common is the sense of challenge to individual wellbeing. The PSS records these challenges based on the interior psychological landscape. The HAUS records these challenges based on the surrounding physical landscape. What can possibly be challenging about the physical landscape of a city block? Consider a block without trees, strewn with litter, and marred by graffiti. Does such a block convey a sense of habitability? People are challenged when they are in uncomfortable environments. Through evolution, humans have learned to recognize the qualities of habitable spaces. Tree canopy is a significant signal of habitability. Upkeep and social order are also important signals. Neither the PSS nor the HAUS is more valid than the other, they just measure different things.

The fourth major contribution of this research is the confirmation that trees, as a landscape feature, have an impact on stress at the block level. The total count of trees on a block can explain as much as $39 \%$ of the neighborhood stress variance. This relationship remains significant even when median income and other block features are factored in. These results are based on the number of trees and not the canopy cover. When using percent canopy cover as the independent variable, the explained variation in community stress drops to a still significant $14 \%$. The data suggests that the benefits of the urban treescape come from small and big trees alike. There is no need to wait decades for trees to grow a large canopy before they contribute to stress reduction in the neighborhood. These results build a strong case for investing in urban tree programs now. Trees on both private and public space make a moderately significant, positive difference in the quality of urban life.

Acknowledgments. Support for this project was provided in part by funding from the College of Agriculture and Natural Resources, University of Delaware. 


\section{LITERATURE CITED}

Adler, N.E., and J. Stewart. 2004. Psychosocial Notebook: Self Esteem. MacArthur/Research Network on SES \& Health. <www. macses.ucsf.edu/research/psychosocial/selfesteem.php $>$

Agyemang, C., C. van Hooijdonk, W. Wendel-Vos, E. Lindeman, K. Stronks, and M. Droomers. 2007. The association of neighbourhood psychosocial stressors and self-rated health in Amsterdam, The Netherlands. Journal of Epidemiology and Community Health 61(12):1042-1049.

Barton, S.S., R. Darke, and G. Schwetz. 2005. A Plan to Preserve and Enhance the Landscape of the Brandywine Valley Scenic Byway. Delaware Greenways.

Bing Maps-Driving Directions, Traffic and Road Conditions. 2014. <www.bing.com>

Bolund, P., and S. Hunhammar. 1999. Ecosystem services in urban areas. Ecological Economics 29(2):293-301.

Cairns, M.A., and R.A. Meganck. 1994. Carbon sequestration, biological diversity, and sustainable development: Integrated forest management. Environmental Management 18(January):13-22.

Cohen, S., T. Kamarck, and R. Mermelstein. 1983. A global measure of perceived stress. Journal of Health and Social Behavior 24(4):385-96.

Cohen, S., R.C. Kessler, and L.U. Gordon (Eds.). 1995. Strategies for measuring stress in studies of psychiatric and physical disorders. pp. 3-26. Measuring Stress: A Guide for Health and Social Scientists. Oxford University Press, Oxford, UK.

Cohen, S., D. Tyrell, and A. Smith. 1993. Negative life events, perceived stress, negative affect, and susceptibility to the common cold. Journal of Personality and Social Psychology 1:131-140.

Comas, S.J., M.A. Carr, and R.J. Alig. 2010. Sustaining America’s urban trees and forests. <https://mi.gov/documents/dnr/SustainingAmericas_333340_7.pdf>

Consumer and Business Guide for Wilmington, Delaware, and Vicinity 2012-2013 Edition. 2012. infoUSA City Directories. $<$ www.infousacity.com>

DeLongis, A., S. Folkman, and R.S. Lazarus. 1988. The impact of daily stress on health and mood: Psychological and social resources as mediators. Journal of Personality and Social Psychology 54(3):486.

Dillman, D.A. 2009. Internet, Mail, and Mixed-Mode Surveys: The Tailored Design Method (third edition). Hoboken, New Jersey, Wiley \& Sons.

Donovan, G.H., Y.L. Michael, D.T. Butry, A.D. Sullivan, and J.M. Chase. 2011. Urban trees and the risk of poor birth outcomes. Health \& Place 17(1):390-93.

Donovan, G.H., and J.P. Prestemon. 2010. The effect of trees on crime in Portland, Oregon. Environment and Behavior 44(1):3-30.

Eitle, D., and R.J. Turner. 2003. Stress exposure, race, and young adult male crime. The Sociological Quarterly 44(2):243-269.

Evans, G.W., and P. Kim. 2010. Multiple risk exposure as a potential explanatory mechanism for the socioeconomic statushealth gradient. Annals of the New York Academy of Sciences 1186(1):174-89.

Google Earth (version 7.1.2.2041). 2013. Mac OS X (10.9.4). English. Google Inc. <www.google.com/earth>

Jiang, B., C.-Y. Chang, and W.C. Sullivan. 2014. A dose of nature: Tree cover, stress reduction, and gender differences. Landscape and Urban Planning 132(December):26-36.
Kuo, F.E., and W.C. Sullivan. 2001a. Environment and crime in the inner city: Does vegetation reduce crime? Environment and Behavior 33(3):343-367.

Kuo, F.E., and W.C. Sullivan. 2001b. Aggression and violence in the inner city, effects of environment via mental fatigue. Environment and Behavior 33(4):543-571.

Lazarus, R.S. 1997. Fifty years of the research and theory of R.S. Lazarus: An analysis of historical and perennial issues. Mahwah, New Jersey, Psychology Press.

Lee, J., Q. Li, L. Tyrvinen, Y. Tsunetsugu, B-J. Park, T. Kagawa, and Y. Miyazaki. 2012. Nature Therapy and Preventive Medicine. In: J. Maddock (Ed.). Public Health: Social and Behavioral Health. InTech. <www.intechopen.com/books/public-health-social-andbehavioral-health/nature-therapy-and-preventive-medicine>

McEwen, B.S., and P.J. Gianaros. 2010. Central role of the brain in stress and adaptation: Links to socioeconomic status, health, and disease. Annals of the New York Academy of Sciences 1186(1):190-222.

Nasar, J.L., and K.M. Jones. 1997. Landscapes of fear and stress. Environment and Behavior 29(3):291-323.

Nelson, R. 2014. These Are America's 10 Most Dangerous Small Cities. Movoto Blog. <www.movoto.com/blog/top-ten/dangerous-small-cities>

Nowak, D.J., and E.G. McPherson. 1993. Quantifying the impact of trees: The Chicago urban forest climate project. FAO Corporate Document Repository, Unasylva 19931:60.

Pathak, V., B.D. Tripathi, and V. K. Mishra. 2007. Dynamics of traffic noise in a tropical city Varanasi and its abatement through vegetation. Environmental Monitoring and Assessment 146(December):67-75.

Sapolsky, R.M. 2004. Why Zebras Don't Get Ulcers. Macmillan, London, UK. 559 pp.

Sapolsky, R.M. 2005. The influence of social hierarchy on primate health. Science 308(5722):648-652.

Sexton, K., and S. H. Linder. 2011. Cumulative risk assessment for combined health effects from chemical and nonchemical stressors. American Journal of Public Health 101(Suppl 1):S81-88.

Smith, G. 2008. Does Gender Influence Online Survey Participation?: A Record-Linkage Analysis of University Faculty Online Survey Response Behavior. ERIC Document Reproduction Service No. ED 501717. <http://works.bepress.com/cgi/viewcontent.cgi? article $=1009 \&$ context $=$ grinell_smith $>$

Steptoe, A., and P. Feldman. 2001. Neighborhood problems as sources of chronic stress: Development of a measure of neighborhood problems, and associations with socioeconomic status and health. Annals of Behavioral Medicine 23(3):177-185.

Targeted Sales Leads | Consumer \& Business Sales Leads | Salesgenie. 2014. <https://salesgenie.com>

Townsend, J.B. 2014. Exploring the Relationship between Trees and Stress in the Urban Environment. University of Delaware. $<$ http://gradworks.umi.com/36/85/3685154.html>

Tyrväinen, L., S. Pauleit, K. Seeland, and S. de Vries. 2005. pp. 81114. Benefits and uses of urban forests and trees. In: C. Konijnendijk, K. Nilsson, T. Randrup, and J. Schipperjin (Eds.). Urban Forests and Trees. Springer-Verlag, Berlin, Germany. pp. 520.

Ulrich, R.S. 1984. View through a window may influence recovery from surgery. Science, New Series 224(4647):420-421. 
Ulrich, R.S., R.F. Simons, B.D. Losito, E. Fiorito, M.A. Miles, and M. Zelson. 1991. Stress recovery during exposure to natural and urban environments. Journal of Environmental Psychology 11(3):201-230.

U.S. EPA. 1986. Guidelines for Health Risk Assessment of Chemical Mixtures. EPA Risk Assessment Forum.

U.S. Census Bureau. 2010. Website Services \& Coordination. U.S. Census Bureau 2010 Census Interactive Population Map. <www.census.gov/2010census/popmap >

Wolf, K.L. 2004. Nature in the retail environment: Comparing consumer and business response to urban forest conditions. Landscape Journal 23(1):40-51.

Joseph B. Townsend (corresponding author)

Adjunct Professor

Department of Plant and Soil Sciences

University of Delaware

Newark, Delaware 19716, U.S.

jtwnsd@udel.edu

Thomas W. Ilvento

Interim Chair, Department of Applied Economics \& Statistics

University of Delaware

Newark, Delaware 19716, U.S.

Susan S. Barton

Associate Professor and Extension Specialist

Department of Plant and Soil Sciences

University of Delaware

Newark, Delaware 19716, U.S.

Résumé. Cette revue de littérature décrit la relation positive entre le fait de voir des végétaux et le bien-être humain. Une récupération plus rapide à la suite d'interventions chirurgicales, la réduction de l'incidence de la criminalité d'un quartier, l'augmentation du poids de nouveaux nés à la naissance et l'augmentation de la confiance des commerçants du voisinage sont parmi les avantages attribués à la présence d’arbres et d’arbustes. Cette étude a tenté de trouver une explication commune à ces résultats. Elle a évalué le lien entre les arbres urbains et les tensions ressenties dans un quartier donné. Chacun des résultats énoncés peut être attribué, en partie, à la réduction du stress. La littérature a démontré que la réduction du stress est l'une des conséquences de l'exposition aux végétaux. Les niveaux de stress ont été mesurés au sein d'un pâté de maisons à Wilmington, au Delaware, États-Unis, au moyen d'un sondage posté à 2,704 résidents. Les conditions physiques ont été cataloguées à l'aide d'un inventaire existant. L'enquête et l'inventaire ont démontré que le nombre total d'arbres d'un pâté de maisons possède une relation négative forte avec les tensions du voisinage et une relation positive avec létat de santé des résidents. Les résultats suggèrent que la modération du stress est l'un des facteurs qui sous-tendent les conséquences bénéfiques de l'exposition à la verdure dans les quartiers déshérités. Cette recherche devrait se révéler autant utile pour les urbanistes que pour les citoyens.

Zammenfassung. Die Literaturrecherche beschreibt eine positive Beziehung zwischen Pflanzen sehen und menschlichem Wohlbefinden. Schnellere Genesung nach operativen Eingriffen, weniger Anzeichen von Kriminalität in der Nachbarschaft, zunehmendes Geburtsgewicht von Kindern und wachsendes Vertrauen der benachbarten Händler sind nur einige von den Vorzügen, die auftreten, wenn Bäume und Sträucher vorhanden sind. Diese Studie versuchte, eine allgemein gültige Erklärung für diese Erscheinungen zu finden. Die Verbindung zwischen Stadtbäumen und Nachbarschaftsstress wurde hier untersucht. Jede der genannten Erscheinungen kann, teilweise, zur Stressreduktion führen. Die Literatur zeigte, dass Stressreduktion eine der Konsequenzen aus der Exposition gegenüber Pflanzen ist. In Wilmington, Delaware, US, wurde in einer postversandten Umfrage der Stresslevel bei 2704 Anwohnern gemessen. Unter Verwendung einer Standorterhebung wurden die physikalischen Konditionen katalogisiert. Die Umfrage und die Inventur demonstrierte, dass die totale Anzahl der Bäume pro Block eine starke negative Beziehung zum Nachbarschaftsstress hat und eine positive Beziehung zu persönlich empfundener Gesundheit. Die Ergebnisse weisen darauf hin, dass der Umgang mit Stress einer der Faktoren ist, der bei den begünstigenden Konsequenzen aus der Exposition gegenüber grüner Vegetation in innerstädtischen Wohnblöcken zugrunde liegt. Diese Forschung sollte sich als gleichzeitig nützlich für Stadtplaner und Anwohner erweisen.

Resumen. La literatura de investigación describe una relación positiva entre las plantas y el bienestar humano. Recuperación más rápida de las cirugías, menor incidencia de crimen en el vecindario, aumento de peso de los bebés recién nacidos, y aumento de la confianza de los comerciantes de los vecindarios son algunos de los beneficios atribuidos a la exposición a los árboles y arbustos. Este estudio intentó encontrar una explicación común para estos resultados. Se examinó la relación entre el estrés y los árboles urbanos. Cada uno de los resultados declarados se puede atribuir, en parte, a la reducción del estrés. La literatura indica que la reducción del estrés es una de las consecuencias de la exposición a las plantas. Los niveles de estrés se midieron a nivel de manzana en Wilmington, Delaware, EE.UU., por medio de una encuesta por correo a 2,704 residentes. Las condiciones físicas fueron catalogadas usando un inventario in situ. La encuesta y el inventario demostraron que el número total de árboles en una manzana tiene una fuerte relación negativa con el estrés barrial y una relación positiva con la percepción subjetiva de la salud. Los resultados sugieren que la moderación de estrés es uno de los factores que subyace a las consecuencias beneficiosas de la exposición a la vegetación en manzanas del centro de la ciudad. Esta investigación puede ser muy útil para los planificadores de la ciudad y los residentes urbanos por igual. 